\title{
Genetics of inflammatory bowel disease: Current status and future directions
}

\author{
Thomas D Walters MBBS FRACP ${ }^{1}$, Mark S Silverberg MD PhD²
}

$\mathrm{T}_{\mathrm{s}}^{\mathrm{h}}$ he genetic analysis of complex diseases has become a mainstream biomedical research goal. The methods for genetically dissecting human diseases have now evolved into an integrated science combining human genetics, functional genomics, high-throughput experimental technology and computational techniques. The inflammatory bowel diseases (IBDs) feature prominently in this field, and the realm of IBD genetics is continually and exponentially increasing. The present review will summarize and put into perspective the breadth of IBD genetics as it has evolved over the past 10 years, and will give the reader some sense of anticipation as to where it may be leading us.

\section{EPIDEMIOLOGY - EVIDENCE FOR A GENETIC ETIOLOGY}

A variety of epidemiological data suggest that genetic factors are intimately involved in the pathogenesis of IBD. For instance, IBD demonstrates a familial pattern of disease with a much higher disease frequency in first-degree relatives of affected individuals compared with the general population (1-4). The degree of 'heritability' or $\lambda_{\mathrm{s}}$ (the relative risk of the sibling of an affected individual) is estimated to range from 15 to 35 for Crohn's disease (CD) and six to nine for ulcerative colitis (UC) (5-9). Twin studies strengthen the argument for a genetic basis for IBD, with a much higher rate of disease concordance demonstrated in monozygotic twins compared with dizygotic twins, particularly in CD (10-13). Marked ethnic and racial differences in disease prevalence have been noted, particularly in Ashkenazi Jews, and are also in keeping with genetic etiology (14-22).

IBD is said to be a complex genetic disorder with the disease appearing to occur in susceptible individuals carrying one or more risk alleles after exposure to one or more environmental triggers. Because there is an increased risk of UC in CD-affected families and vice versa, a genetic model is proposed in which $\mathrm{CD}$ and UC are related diseases sharing some susceptibility loci but perhaps differing at others, which results in diverging disease courses $(23,24)$. Additional genetic 'hits' or environmental factors may determine the particular phenotype of the individual by influencing features such as disease site, disease behaviour or response to therapy, among others (Figure 1).

\section{GENE IDENTIFICATION TECHNIQUES}

The quest for IBD susceptibility genes has used two broad approaches: linkage analysis using multiple-affected families and association using affected individuals in a case-control format. Genome-wide scans (GWSs) were traditionally used only with linkage analysis but recent progress has allowed a genome-wide approach by case-control association studies. Given the almost infinite number of possible genetic candidates, it is not surprising that the first major advances in this area were generated by linkage analysis: a 'hypothesis-free' technique in which the entire genome can be evaluated to look for areas of genetic susceptibility before trying to narrow down the search to specific genes. A genome-wide linkage analysis usually requires the ascertainment of numerous 'sibling pair' families, that is, two affected siblings and their parents (whether affected or not). Genotyping of all the members of each family is performed for polymorphic DNA microsatellite markers (approximately 300 microsatellite markers), which are located at intervals throughout the genome. Linkage analysis generates $\log$ of odds (LOD) scores which are measures of excess sharing of the same allele between affected siblings, suggesting a correlation between inheritance of disease and inheritance of that particular allele (Figure 1). This allows for the narrowing down of the search for susceptibility genes to a more specific part of the genome. Numerous genome-wide linkage studies in IBD have been published since 1996, identifying at least nine susceptibility loci (IBD1 - IBD9) thought to contain causal genes (Table 1).

On the other hand, candidate gene analysis to some extent is hypothesis driven. It is an 'association test' that examines differences in the allele frequencies of the nominated gene in affected patients compared with controls. A variety of different statistical techniques can be used and the controls can be 'population-based' controls who must be carefully matched, or family-based controls who are often the parents of the affected individual. The chosen 'candidate' is usually based on findings from an earlier linkage study putting that gene within the susceptibility region identified in a prior GWS (a positional candidate) or by the purported function of the gene such as tumour necrosis factor-alpha (TNF- $\alpha$ ) (a functional candidate). These approaches are certainly complementary, and ideally, both approaches are required in tandem, as was illustrated with the identification of the first IBD susceptibility gene described below. More recently, single nucleotide polymorphisms (SNPs) have been used in the place of microsatellite markers for the purpose of performing genome-wide association studies. SNPs represent sites along the genome in which a single base pair variation occurs from person to person where the least frequent allele has a frequency of $1 \%$ or greater. Many SNPs occur within genes, with some representing variations that alter gene function and may even represent the genetic lesion of interest.

\footnotetext{
${ }^{1}$ Department of Paediatrics, The Hospital for Sick Children, University of Toronto; ${ }^{2}$ Department of Medicine, Mount Sinai Hospital Inflammatory Bowel Disease Centre, University of Toronto, Toronto, Ontario

Correspondence: Dr Mark S Silverberg, Mount Sinai Hospital Inflammatory Bowel Disease Centre, Room 441, 600 University Avenue, Toronto, Ontario M5G 1X5. Telephone 416-586-8236, fax 416-586-4878, e-mail msilverberg@mtsinai.on.ca
} 


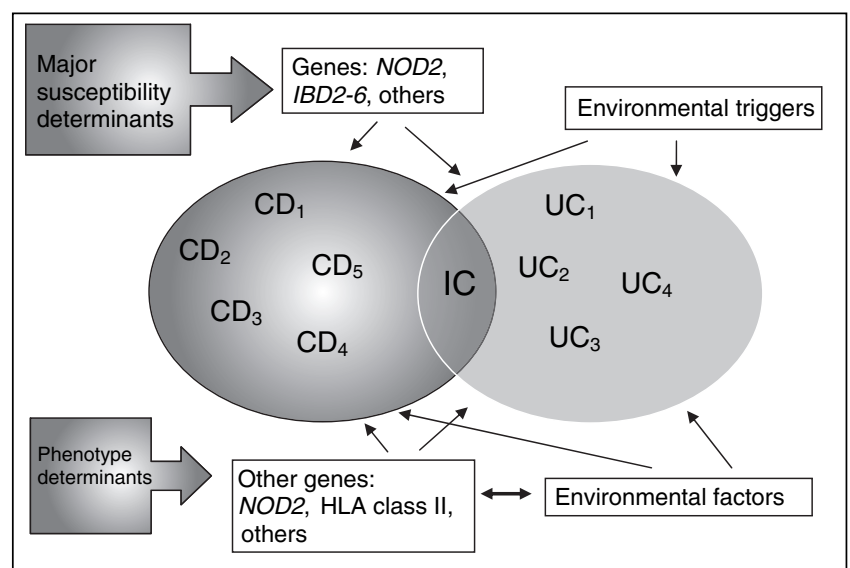

Figure 1) Gene-environment interactions in inflammatory bowel disease (IBD). CD Crohn's disease; HLA Human leukocyte antigen; IC Indeterminate colitis; NOD2 Nucleotide oligomerization domain 2; UC Ulcerative colitis

Genome-wide association studies may represent the most powerful approach to identifying all of the IBD susceptibility genes that are relevant to disease pathophysiology because as many as 500,000 SNPs could be assayed for each patient in the study, making a massive amount of data available for analysis.

\section{CARD15/NOD2 AND CD SUSCEPTIBILITY}

In 2001, two groups identified the first gene contributing to CD susceptibility within the IBD1 susceptibility locus on chromosome 16. This gene was known as caspase activating recruitment domain 15 (CARD15) or nucleotide-binding oligomerization domain 2 (NOD2) $(25,26)$, and is the only confirmed susceptibility gene to date for IBD. Three major independent polymorphisms of this gene are associated with CD in Caucasians: Arg702Trp and Gly908Arg are both missense mutations resulting in an amino acid substitution, as well as Leu1007fsinsC, which is a frameshift mutation that results in shortening of the protein product $(25,27-43)$. While the identified mutations are either rare or absent in Asian $(32,33,44-46)$, Arab $(47,48)$ and African (49) populations, it is estimated that $27 \%$ to $38 \%$ of Caucasian CD patients carry one of the major risk alleles (compared with approximately $20 \%$ of Caucasian controls) and an additional 8\% to 17\% carry two copies (compared with less than $1 \%$ of controls). Of note, allele frequency for the three common mutations in sporadic $\mathrm{CD}$ is comparable with that seen in familial CD. A recent meta-analysis (50) calculated that the overall relative risk of developing CD in Caucasian populations was 2.4 (95\% CI 2.0 to 2.9) for carriers of one mutant allele and 17.1 (95\% CI 10.7 to 27.2) for two or more mutant copies. The risk varied with each mutation, Leu1007fsinsC generally carrying the highest risk and Arg702Trp the lowest. The overall proportion of CD cases attributed to the presence of mutant alleles in Caucasian populations was approximately $22 \%(50)$.

Further evaluation of CARD15/NOD2 risk alleles have demonstrated a number of phenotypic associations. The major variants are associated with earlier age of onset $(27,51,52)$ and ileal disease location (27-30,35,42,52-54). They are also suggested to be associated with fibrostenotic disease behaviour, $(29,30,34,36,51,52,55)$ and negatively associated with pure colonic disease $(27,30,35,42,43,51,52)$. In summary, the evidence to date suggests that the three risk alleles within the
TABLE 1

Inflammatory bowel disease (IBD) susceptibility loci

\begin{tabular}{lccc}
\hline Chromosome & HUGO ID & Phenotype & Associations \\
\hline $16 q$ & IBD1 & CD & NOD2/CARD15 \\
$12 q$ & IBD2 & IBD, especially UC & \\
$6 p$ & $I B D 3$ & IBD & HLA, TNF \\
$14 q$ & IBD4 & CD & \\
$5 q$ & $I B D 5$ & IBD & IBD5 haplotype, \\
& & & OCTN1 and OCTN2 \\
$19 p$ & $I B D 6$ & IBD & \\
$1 p$ & $I B D 7$ & IBD & \\
$3 p$ & $I B D 9$ & IBD & \\
\hline
\end{tabular}

CD Crohn's disease; HUGO ID Human genome organization identification; HLA Human leukocyte antigen; NOD2/CARD15 Nucleotide-binding oligomerization domain 2/Caspase activating recruitment domain 15; OCTN Organic cation transporter; TNF Tumour necrosis factor; UC Ulcerative colitis

CARD15/NOD2 gene are correlated with CD which has an earlier onset, involves the ileum and is frequently fibrostenoic.

\section{OTHER IMPORTANT IBD LOCI}

To date, CARD15/NOD2 is the only confirmed IBD susceptibility gene identified. There are a number of other likely candidate genes and loci that have been described, although details remain less clear, and their roles less well characterized than CARD15/NOD2.

\section{The IBD5 locus on chromosome $5 \mathrm{q} 31$}

The IBD5 locus on chromosome $5 \mathrm{q} 31$ has received much attention recently. Aside from CARD15/NOD2, it is the next most relevant region for IBD susceptibility. The locus was initially identified as significant by two GWSs $(56,57)$. Subsequent analyses refined the locus to a $250 \mathrm{~kb}$ risk haplotype (58). The association of this haplotype with IBD has been widely replicated in a number of independent populations (59-62). The IBD5 risk haplotype has been principally associated with $\mathrm{CD}$, although there have been some suggestions of a weak association with UC as well. Polymorphisms within the organic cation transporter (OCTN1 and OCTN2) genes in the region have been recently put forward as the causative variant based on a combination of functional and genetic evidence (63). OCTN1 and OCTN2 are transporters that mediate transmembrane transport of carnitine and other organic cations $(64,65)$. Although putative mechanisms have been suggested (65), no direct evidence is available to date to explain the role the variants of these genes could play in the pathobiology of IBD. Despite the efforts of several large centres, there has been an inability to replicate the findings that OCTN1 and OCTN2 polymorphisms are independently associated with CD, and these additional studies (66-69) support the possibility that the OCTN1 and OCTN2 SNPs are simply part of the extended haplotype in the region. This region is particularly difficult to fine map because it contains a significant degree of linkage disequilibrium, making it difficult to discern a causative allele from a marker allele coinherited with the disease-causing allele $(58,70)$.

Phenotypically, the IBD5 locus has been associated with earlier onset disease (56) as well as perianal disease $(61,67)$. While most commonly reported with $\mathrm{CD}$, an association with UC has been reported (62) with the strength of both associations possibly increased in the presence of a known CARD15/NOD2 
variant $(60,71)$ suggesting a positive epistatic interaction (the influence of one gene on the expression of another). With the uncertainty over the role of OCTN1 and OCTN2, attention has focused on a number of additional genes located within the IBD5 locus. These have included genes within the cytokine cluster, as well as interferon regulatory factor 1, PDLIM and proline 4-hydroxylase alpha polypeptide II, all of which are equally likely to contain the IBD5 causal variant as the OCTN genes.

\section{THE MAJOR HISTOCOMPATIBILITY COMPLEX REGION (IBD3) ON CHROMOSOME 6P}

Linkage of IBD (both $\mathrm{UC}$ and $\mathrm{CD}$ ) to the IBD3 region on chromosome 6 has been confirmed in a variety of GWSs $(56,57,72-74)$. In a recent meta-analysis (75) of 10 such scans, it was the only locus that achieved genome-wide significance. The IBD3 region contains the major histocompatibility complex genes (also referred to as the human leukocyte antigen [HLA]). The HLA complex is divided into three regions (class I, class II and class III) and contains a total of 224 densely packed highly polymorphic gene loci (76). Not surprisingly, the study of this area has proved very challenging, with various conflicting results. Several linkage and association studies $(56,73,74,77-80)$ have implicated the HLA region in both IBD susceptibility and phenotype, although it has not been consistently confirmed in replication studies (81). A recent metaanalysis of 20 studies (82) highlighted both positive and negative associations with a variety of class II DRB1 alleles. For example, DRB1*1502 is associated with UC across a variety of different populations. Despite extremely variable background prevalence (from less than $1 \%$ in Northern Europeans to approximately $25 \%$ in Japanese) the relative risk in each ethnic group is surprisingly similar (two to 4.5) (80,83-86). This pattern suggests the allele is a susceptibility variant.

However, genetic variation may not only contribute to susceptibility, but may also modify disease phenotype. Indeed, multiple-affected families show surprising concordance for disease phenotype, including age of onset, disease location, behaviour, need for surgery and extraintestinal manifestations $(3,87-90)$. It is possible that HLA plays a greater role in determining final disease phenotype than initial disease susceptibility (76). For instance, DRB1*07 is the most consistently replicated association with CD. It is specifically associated with ileal disease in the absence of a major CARD15/NOD2 mutation (27,28,82,91). In comparison, DRB1*0103 is a rare allele that has been associated with both UC and CD. In UC, it is the most consistently replicated HLA association. In UC, the association has been reported across a variety of ethnic groups in combination with various haplotypes, and is particularly strong in patients with extensive or severe disease $(80,83,92-95)$. In CD, the allele is strongly associated with isolated colonic disease $(27,28,91,96)$. Interestingly, this allele (along with HLA-B*27) has also been associated with uveitis (97). In addition, DRB1*0103 (as well as B*27 and $B * 35)$ has been associated with type I peripheral arthropathy (acute, self-limiting, pauciarticular large-joint arthritis associated with IBD relapses) while HLA-B*44 has been associated with type II arthritis (symmetrical, seronegative, small-joint arthropathy unrelated to disease activity) (98).

Many of the genes in this region are also involved in the immune response and include the genes for TNF, lymphotoxin alpha and the heat shock proteins. Of these, TNF is certainly the most intensely studied. Associations have been found with CD and promoter polymorphisms at positions $-308,-857,-863$ and -1031 ; however, their functional significance remains unclear $(27,99-106)$.

\section{DROSOPHILA DISCS LARGE HOMOLOGUE 5 (DLG5) AND IBD SUSCEPTIBILITY}

The pericentromeric region of chromosome 10 was identified as a potential IBD susceptibility locus in a European GWS. More recently, the region was refined to a haplotype block that contained only one gene: drosophila discs large homologue 5 (DLG5) (107). The data suggested an overall association for DLG5 with IBD susceptibility rather than just CD, with a relative risk of approximately 1.5 (107). These findings have been, at least, partially replicated in some centres $(108,109)$, but not in the majority of studies $(67,110,111)$. DLG5 is an attractive susceptibility candidate because it is putatively involved in maintaining epithelial integrity, and thus, its dysfunction would be consistent with an etiological model of impaired barrier function. However, much work remains to be performed to ascertain the role of this gene in IBD susceptibility.

\section{MULTIDRUG RESISTANCE-1 GENE AND IBD SUSCEPTIBILITY}

The multidrug resistance-1 (MDR1) gene is a biologically plausible candidate gene for a number of reasons. First, MDR1deficient mice are known to spontaneously develop enterocolitis when maintained in a specific pathogen-free environment (112). The gene's product, P-glycoprotein 170, is highly expressed in various epithelial surfaces including the intestine. Langmann et al (113) recently demonstrated a marked downregulation of this product in the colonic tissue of UC patients but not CD patients. Finally, the MDR-1 gene maps to chromosome 7q22 in a region that was previously identified by a GWS as being suggestive for linkage to IBD (114). To date, the most consistently reported association is with UC (115-118). Ho et al (115) described two haplotypes, one associated with disease susceptibility and the other disease protective. Current data suggest a specific association with extensive UC (115). The exact physiological role of this protein within the gut remains controversial. A variety of other case-control studies $(119,120)$ have failed to detect any association between this gene variant and UC.

\section{CLINICAL IMPLICATIONS}

The field of IBD genetics is in its infancy despite relatively rapid success in a number of areas. The integration of genetic testing into the clinic is still premature, however, it will not be long before genetic testing may become an important part of the initial workup of a patient with suspected or known IBD (Table 2).

The use of genetic testing to predict disease in presymptomatic patients is still not possible due to the relative lack of sensitivity and specificity of CARD15/NOD2 testing. The same argument applies to genetic testing for diagnosis of IBD and the early presentation of IBD patients. It is more plausible that in the future, a panel of genetic and possibly serum markers will be tested to provide a measure of how likely a person is to develop IBD and what a patient's diagnosis is after symptoms have begun. Prognostic testing in individuals diagnosed with IBD is an area where molecular testing of genetic and serum markers 


\begin{tabular}{l} 
TABLE 2 \\
Potential application of genetic testing in inflammatory \\
bowel disease \\
\hline Prediction of disease susceptibility \\
Presymptomatic testing to detect 'at risk' individuals \\
Diagnosis \\
Prognosis \\
Choice of therapy and response to therapy \\
Disease prevention with specific interventions \\
Do not smoke? \\
Avoid unnecessary nonsteroidal anti-inflammatory drugs? \\
Probiotics administration? \\
Gene therapy?
\end{tabular}

may have the most potential current value. For example, it is known that CARD15/NOD2-positive individuals are more likely to have ileal disease and fibrostenotic disease, and are potentially more likely to proceed to an early ileal resection (121). If this is confirmed, then testing may allow the identification of those at risk of this complication and potentially target earlier or more advanced therapies to these individuals to prevent such complications. Again, a panel of genetic markers will likely be more useful for this indication. This type of predictive testing is evolving in serological marker testing where combinations of markers are associated with more aggressive small-bowel $\mathrm{CD}$ with a predilection to advanced disease behaviour (such as fibrostenotic or internal penetrating disease). Indeed, it is possible that the presence of such serum markers is genetically mediated and that ultimately a combination of genetic and serum marker testing will predict the course of the disease.

Pharmacogenetics is the study of how genetic variation influences an individuals' response to therapy $(122,123)$. The hypothesis is that characterization of a specific genetic polymorphism will predict drug response and/or toxicity. It has been estimated that genetic variation can account for $20 \%$ to $90 \%$ of variability in drug disposition and effect (124). A classic example of the role of pharmacogenetics in IBD is the utility of thiopurine methyltransferase (TPMT) genotyping and the relationship to the metabolism of azathioprine/6-mercaptopurine. TPMT is one of the main degradation enzymes for these drugs,

\section{REFERENCES}

1. Binder V. Genetic epidemiology in inflammatory bowel disease. Dig Dis 1998;16:351-5.

2. Russel MG, Pastoor CJ, Janssen KM, et al. Familial aggregation of inflammatory bowel disease: A population-based study in South Limburg, The Netherlands. The South Limburg IBD Study Group. Scand J Gastroenterol Suppl 1997;223:88-91.

3. Peeters M, Nevens H, Baert F, et al. Familial aggregation in Crohn's disease: Increased age-adjusted risk and concordance in clinical characteristics. Gastroenterology 1996;111:597-603.

4. Farmer RG, Michener WM, Mortimer EA. Studies of family history among patients with inflammatory bowel disease. Clin Gastroenterol 1980;9:271-7.

5. Satsangi J, Jewell DP, Rosenberg WM, Bell JI. Genetics of inflammatory bowel disease. Gut 1994;35:696-700.

6. Probert CS, Jayanthi V, Hughes AO, Thompson JR, Wicks AC, Mayberry JF. Prevalence and family risk of ulcerative colitis and Crohn's disease: An epidemiological study among Europeans and south Asians in Leicestershire. Gut 1993;34:1547-51.

7. Kuster W, Pascoe L, Purrmann J, Funk S, Majewski F. The genetics of Crohn disease: Complex segregation analysis of a family study with and mutations within this gene have been associated with toxic side effects. However, the appropriate clinical application of this knowledge is still debated. While one might hypothesize that knowledge of the genotype could avoid toxicity, it is important to note that TPMT mutations appear to only account for approximately $10 \%$ to $27 \%$ of observed toxic reactions (125-128). Recent work with MDR-1 introduced the potential ability to predict steroid resistance with the suggestion that there is an overexpression of MDR-1 in the peripheral blood lymphocytes of steroid-resistant IBD patients (129). Hoffmeyer et al (130) have demonstrated an association with a specific variant of this gene (SNP C3235T) and its in vivo expression levels. In the future, it may be possible to predict a patient's steroid responsiveness from a genetic test $(122,131)$. Conversely, as discussed earlier, an association was demonstrated with underexpression of MDR-1 and the development of colitis. Pharmacogenetic studies are being undertaken in virtually all current IBD therapies, however, to date, there are minimal data available that would yield an impact upon clinical care.

\section{FUTURE DIRECTIONS}

While each individual genetic risk factor identified thus far for IBD accounts for very little of the disease's overall heritability, the interaction between these and other genes as well as between genes and environmental risk factors is likely to play a very important role in disease pathogenesis and outcome. With advances in genetic technology leading to genome-wide association testing about to be completed in IBD, it is much more likely that all of the important genetic variants that contribute to IBD susceptibility will be identified. This will initiate an era of tremendous promise in the field of IBD research with the unique opportunity to make real advances in understanding the cause of IBD and to enable us to reach the goal of disease prevention and possibly a cure. While this is surely to take many years of painstaking work, the discoveries in IBD genetics will provide many ways to improve the lives of those living with IBD and make more tools available to those treating IBD. With improvements in diagnostic and prognostic testing as well as the development of novel drugs or drug tools to enable us to use existing therapies more effectively, the field of IBD genetics places us at the dawn of a new horizon in our efforts to better understand and manage IBD.
265 patients with Crohn disease and 5387 relatives. Am J Med Genet 1989;32:105-8

8. Meucci G, Vecchi M, Torgano G, et al. Familial aggregation of inflammatory bowel disease in northern Italy: A multicenter study. The Gruppo di Studio per le Malattie Infiammatorie Intestinali (IBD Study Group). Gastroenterology 1992;103:514-9.

9. Orholm M, Munkholm P, Langholz E, Nielsen OH, Sorensen TI, Binder V. Familial occurrence of inflammatory bowel disease. N Engl J Med 1991;324:84-8.

10. Halfvarson J, Bodin L, Tysk C, Lindberg E, Jarnerot G. Inflammatory bowel disease in a Swedish twin cohort: A long-term follow-up of concordance and clinical characteristics. Gastroenterology 2003;124:1767-73.

11. Orholm M, Binder V, Sorensen TI, Rasmussen LP, Kyvik KO. Concordance of inflammatory bowel disease among Danish twins. Results of a nationwide study. Scand J Gastroenterol 2000;35:1075-81.

12. Thompson NP, Driscoll R, Pounder RE, Wakefield AJ. Genetics versus environment in inflammatory bowel disease: Results of a British twin study. BMJ 1996;312:95-6. 
13. Tysk C, Lindberg E, Jarnerot G, Floderus-Myrhed B. Ulcerative colitis and Crohn's disease in an unselected population of monozygotic and dizygotic twins. A study of heritability and the influence of smoking. Gut 1988;29:990-6.

14. Thomas GA, Millar-Jones D, Rhodes J, Roberts GM, Williams GT, Mayberry JF. Incidence of Crohn's disease in Cardiff over 60 years: 1986-1990 an update. Eur J Gastroenterol Hepatol 1995;7:401-5.

15. Yapp TR, Stenson R, Thomas GA, Lawrie BW, Williams GT, Hawthorne AB. Crohn's disease incidence in Cardiff from 1930: An update for 1991-1995. Eur J Gastroenterol Hepatol 2000;12:907-11.

16. Trallori G, Palli D, Saieva C, et al. A population-based study of inflammatory bowel disease in Florence over 15 years (1978-92) Scand J Gastroenterol 1996;31:892-9.

17. Ogunbi SO, Ransom JA, Sullivan K, Schoen BT, Gold BD. Inflammatory bowel disease in African-American children living in Georgia. J Pediatr 1998;133:103-7.

18. Loftus EV Jr, Silverstein MD, Sandborn WJ, Tremaine WJ, Harmsen WS, Zinsmeister AR. Crohn's disease in Olmsted County, Minnesota, 1940-1993: Incidence, prevalence, and survival. Gastroenterology 1998;114:1161-8. (Erratum in 1999;116:1507).

19. Andres PG, Friedman LS. Epidemiology and the natural course of inflammatory bowel disease. Gastroenterol Clin North Am 1999;28:255-81, vii.

20. Bernstein CN, Blanchard JF, Rawsthorne P, Wajda A. Epidemiology of Crohn's disease and ulcerative colitis in a central Canadian province: A population-based study. Am J Epidemio 1999; 149:916-24

21. Yang SK, Loftus EV Jr, Sandborn WJ. Epidemiology of inflammatory bowel disease in Asia. Inflamm Bowel Dis 2001;7:260-70.

22. Carr I, Mayberry JF. The effects of migration on ulcerative colitis: A three-year prospective study among Europeans and first- and second-generation South Asians in Leicester (1991-1994). Am J Gastroenterol 1999;94:2918-22.

23. Satsangi J, Jewell DP, Bell JI. The genetics of inflammatory bowel disease. Gut 1997;40:572-4.

24. Ahmad T, Satsangi J, McGovern D, Bunce M, Jewell DP. Review article: The genetics of inflammatory bowel disease. Aliment Pharmacol Ther 2001;15:731-48.

25. Hugot JP, Chamaillard M, Zouali $\mathrm{H}$, et al. Association of NOD2 leucine-rich repeat variants with susceptibility to Crohn's disease. Nature 2001;411:599-603.

26. Ogura $\mathrm{Y}$, Bonen DK, Inohara N, et al. A frameshift mutation in NOD2 associated with susceptibility to Crohn's disease. Nature 2001;411:603-6.

27. Ahmad T, Armuzzi A, Bunce M, et al. The molecular classification of the clinical manifestations of Crohn's disease. Gastroenterology 2002;122:854-66. (Erratum in 2003;125:281).

28. Newman B, Silverberg MS, Gu X, et al. CARD15 and HLA DRB1 alleles influence susceptibility and disease localization in Crohn's disease. Am J Gastroenterol 2004:99:306-15.

29. Linskens RK, Mallant-Hent RC, Murillo LS, von Blomberg BM, Alizadeh BZ, Pena AS. Genetic and serological markers to identify phenotypic subgroups in a Dutch Crohn's disease population. Dig Liver Dis 2004;36:29-34.

30. Vavassori P, Borgiani P, Biancone L, et al. CARD15 mutation analysi in an Italian population: Leu1007fsinsC but neither Arg702Trp nor Gly908Arg mutations are associated with Crohn's disease. Inflamm Bowel Dis 2004;10:116-21.

31. Buning C, Genschel J, Buhner S, et al. Mutations in the NOD2/CARD15 gene in Crohn's disease are associated with ileocecal resection and are a risk factor for reoperation. Aliment Pharmacol Ther 2004;19:1073-8

32. Yamazaki K, Takazoe M, Tanaka T, Kazumori T, Nakamura Y. Absence of mutation in the NOD2/CARD15 gene among 483 Japanese patients with Crohn's disease. J Hum Genet 2002:47:469-72. (Erratum in 2003:48:397).

33. Inoue N, Tamura K, Kinouchi Y, et al. Lack of common NOD2 variants in Japanese patients with Crohn's disease. Gastroenterology 2002;123:86-91

34. Heresbach D, Gicquel-Douabin V, Birebent B, et al. NOD2/CARD15 gene polymorphisms in Crohn's disease: A genotype-phenotype analysis. Eur J Gastroenterol Hepatol 2004; 16:55-62.

35. Cuthbert AP, Fisher SA, Mirza MM, et al. The contribution of NOD2 gene mutations to the risk and site of disease in inflammatory bowel disease. Gastroenterology 2002;122:867-74.
36. Abreu MT, Taylor KD, Lin YC, et al. Mutations in NOD2 are associated with fibrostenosing disease in patients with Crohn's disease Gastroenterology 2002;123:679-88.

37. Zhou Z, Lin XY, Akolkar PN, et al. Variation at NOD2/CARD15 in familial and sporadic cases of Crohn's disease in the Ashkenazi Jewish population. Am J Gastroenterol 2002;97:3095-101.

38. Cavanaugh JA, Adams KE, Quak EJ, et al. CARD15/NOD2 risk alleles in the development of Crohn's disease in the Australian population. Ann Hum Genet 2003;67(Pt 1):35-41.

39. Bonen DK, Ogura Y, Nicolae DL, et al. Crohn's disease-associated NOD2 variants share a signaling defect in response to lipopolysaccharide and peptidoglycan. Gastroenterology 2003;124:140-7.

40. Hampe J, Cuthbert A, Croucher PJ, et al. Association between insertion mutation in NOD2 gene and Crohn's disease in German and British populations. Lancet 2001;357:1925-8. (Erratum in 2002;360:806)

41. Vavassori P, Borgiani P, D’Apice MR, et al. 3020insC mutation within the NOD2 gene in Crohn's disease: Frequency and association with clinical pattern in an Italian population. Dig Liver Dis 2002;34:153. (Lett)

42. Vermeire S, Wild G, Kocher K, et al. CARD15 genetic variation in a Quebec population: Prevalence, genotype-phenotype relationship, and haplotype structure. Am J Hum Genet 2002;71:74-83.

43. Esters N, Pierik M, van Steen K, et al. Transmission of CARD15 (NOD2) variants within families of patients with inflammatory bowel disease. Am J Gastroenterol 2004;99:299-305.

44. Guo QS, Xia B, Jiang Y, Qu Y, Li J. NOD2 3020insC frameshift mutation is not associated with inflammatory bowel disease in Chinese patients of Han nationality. World J Gastroenterol 2004:10:1069-71.

45. Croucher PJ, Mascheretti S, Hampe J, et al. Haplotype structure and association to Crohn's disease of CARD15 mutations in two ethnically divergent populations. Eur J Hum Genet 2003;11:6-16.

46. Leong RW, Armuzzi A, Ahmad T, et al. NOD2/CARD15 gene polymorphisms and Crohn's disease in the Chinese population. Aliment Pharmacol Ther 2003;17:1465-70.

47. Karban A, Dagan E, Eliakim R, et al. Prevalence and significance of mutations in the familial Mediterranean fever gene in patients with Crohn's disease. Genes Immun 2005;6:134-9.

48. Zouiten-Mekki L, Zaouali H, Boubaker J, et al. CARD15/NOD2 in a Tunisian population with Crohn's disease. Dig Dis Sci 2005;50:130-5

49. Zaahl MG, Winter T, Warnich L, Kotze MJ. Analysis of the three common mutations in the CARD15 gene (R702W, G908R and $1007 \mathrm{fs}$ ) in South African colored patients with inflammatory bowel disease. Mol Cell Probes 2005;19:278-81.

50. Economou M, Trikalinos TA, Loizou KT, Tsianos EV, Ioannidis JP. Differential effects of NOD2 variants on Crohn's disease risk and phenotype in diverse populations: A metaanalysis. Am J Gastroenterol 2004;99:2393-404

51. Lesage S, Zouali H, Cezard JP, et al; EPWG-IBD Group; EPIMAD Group; GETAID Group. CARD15/NOD2 mutational analysis and genotype-phenotype correlation in 612 patients with inflammatory bowel disease. Am J Hum Genet 2002;70:845-57.

52. Brant SR, Picco MF, Achkar JP, et al. Defining complex contributions of NOD2/CARD15 gene mutations, age at onset, and tobacco use on Crohn's disease phenotypes. Inflamm Bowel Dis 2003;9:281-9

53. Helio T, Halme L, Lappalainen M, et al. CARD15/NOD2 gene variants are associated with familially occurring and complicated forms of Crohn's disease. Gut 2003;52:558-62.

54. Hampe J, Grebe J, Nikolaus S, et al. Association of NOD2 (CARD 15) genotype with clinical course of Crohn's disease: A cohort study. Lancet 2002;359:1661-5.

55. Radlmayr M, Torok HP, Martin K, Folwaczny C. The c-insertion mutation of the NOD2 gene is associated with fistulizing and fibrostenotic phenotypes in Crohn's disease. Gastroenterology 2002;122:2091-2. (Lett)

56. Rioux JD, Silverberg MS, Daly MJ, et al. Genomewide search in Canadian families with inflammatory bowel disease reveals two novel susceptibility loci. Am J Hum Genet 2000;66:1863-70.

57. Ma Y, Ohmen JD, Li Z, et al. A genome-wide search identifies potential new susceptibility loci for Crohn's disease. Inflamm Bowel Dis 1999;5:271-8. 
58. Rioux JD, Daly MJ, Silverberg MS, et al. Genetic variation in the $5 \mathrm{q} 31$ cytokine gene cluster confers susceptibility to Crohn disease. Nat Genet 2001;29:223-8.

59. Negoro K, McGovern DP, Kinouchi Y, et al. Analysis of the IBD5 locus and potential gene-gene interactions in Crohn's disease. Gut 2003;52:541-6.

60. Mirza MM, Fisher SA, King K, et al. Genetic evidence for interaction of the $5 \mathrm{q} 31$ cytokine locus and the CARD15 gene in Crohn disease. Am J Hum Genet 2003;72:1018-22.

61. Armuzzi A, Ahmad T, Ling KL, et al. Genotype-phenotype analysis of the Crohn's disease susceptibility haplotype on chromosome $5 \mathrm{q} 31$. Gut 2003;52:1133-9.

62. Giallourakis C, Stoll M, Miller K, et al. IBD5 is a general risk factor for inflammatory bowel disease: Replication of association with Crohn disease and identification of a novel association with ulcerative colitis. Am J Hum Genet 2003;73:205-11.

63. Peltekova VD, Wintle RF, Rubin LA, et al. Functional variants of OCTN cation transporter genes are associated with Crohn disease. Nat Genet 2004;36:471-5.

64. Yabuuchi H, Tamai I, Nezu J, et al. Novel membrane transporter OCTN1 mediates multispecific, bidirectional, and $\mathrm{pH}$-dependent transport of organic cations. J Pharmacol Exp Ther 1999;289:768-73

65. Newman B, Siminovitch KA. Recent advances in the genetics of inflammatory bowel disease. Curr Opin Gastroenterol 2005;21:401-7.

66. Noble CL, Nimmo ER, Drummond $\mathrm{H}$, et al. The contribution of OCTN1/2 variants within the IBD5 locus to disease susceptibility and severity in Crohn's disease. Gastroenterology 2005;129:1854-64.

67. Vermeire S, Pierik M, Hlavaty T, et al. Association of organic cation transporter risk haplotype with perianal penetrating Crohn's disease but not with susceptibility to IBD. Gastroenterology 2005;129:1845-53.

68. Silverberg MS, Lewinger JP, Walters TD, Sherman PS, Griffiths AM. The IBD5 (5q31) locus is strongly associated with pediatric onset inflammatory bowel disease. Gastroenterology 2005;128(4 Suppl 2):A-137. (Abst)

69. Silverberg MS, Cho JH, Duerr RH, et al. Association of the IBD5 locus With inflammatory bowel disease in a very large north American population. Gastroenterology 2005;128(4 Supp 2):A-137. (Abst)

70. Daly MJ, Rioux JD, Schaffner SF, Hudson TJ, Lander ES. High-resolution haplotype structure in the human genome. Nat Genet 2001;29:229-32.

71. McGovern DP, Van Heel DA, Negoro K, Ahmad T, Jewell DP. Further evidence of IBD5/CARD15 (NOD2) epistasis in the susceptibility to ulcerative colitis. Am J Hum Genet 2003;73:1465-6. (Lett)

72. Dechairo B, Dimon C, van Heel D, et al. Replication and extension studies of inflammatory bowel disease susceptibility regions confirm linkage to chromosome 6p (IBD3). Eur J Hum Genet 2001;9:627-33.

73. Hampe J, Schreiber S, Shaw SH, et al. A genomewide analysis provides evidence for novel linkages in inflammatory bowel disease in a large European cohort. Am J Hum Genet 1999;64:808-16.

74. Hampe J, Shaw SH, Saiz R, et al. Linkage of inflammatory bowel disease to human chromosome 6p. Am J Hum Genet 1999:65:1647-55.

75. van Heel DA, Fisher SA, Kirby A, Daly MJ, Rioux JD, Lewis CM; Genome Scan Meta-Analysis Group of the IBD International Genetics Consortium. Inflammatory bowel disease susceptibility loci defined by genome scan meta-analysis of 1952 affected relative pairs. Hum Mol Genet 2004;13:763-70.

76. Yap LM, Ahmad T, Jewell DP. The contribution of HLA genes to IBD susceptibility and phenotype. Best Pract Res Clin Gastroenterol 2004:18:577-96.

77. Yang H, Plevy SE, Taylor K, et al. Linkage of Crohn's disease to the major histocompatibility complex region is detected by multiple non-parametric analyses. Gut 1999;44:519-26.

78. Reinshagen M, Loeliger C, Kuehnl P, et al. HLA class II gene frequencies in Crohn's disease: A population based analysis in Germany. Gut 1996;38:538-42

79. Danze PM, Colombel JF, Jacquot S, et al. Association of HLA class Il genes with susceptibility to Crohn's disease. Gut 1996;39:69-72.

80. Trachtenberg EA, Yang H, Hayes E, et al. HLA class II haplotype associations with inflammatory bowel disease in Jewish (Ashkenazi) and non-Jewish caucasian populations. Hum Immunol $2000 ; 61: 326-33$
81. Annese V, Piepoli A, Latiano A, et al. HLA-DRB1 alleles may influence disease phenotype in patients with inflammatory bowel disease: A critical reappraisal with review of the literature. Dis Colon Rectum 2005;48:57-64; discussion 64-5.

82. Stokkers PC, Reitsma PH, Tytgat GN, van Deventer SJ HLA-DR and -DQ phenotypes in inflammatory bowel disease: A meta-analysis. Gut 1999;45:395-401.

83. Ahmad T, Armuzzi A, Neville M, et al. The contribution of human leucocyte antigen complex genes to disease phenotype in ulcerative colitis. Tissue Antigens 2003;62:527-35.

84. Futami S, Aoyama N, Honsako Y, et al. HLA-DRB1*1502 allele, subtype of DR15, is associated with susceptibility to ulcerative colitis and its progression. Dig Dis Sci 1995;40:814-8.

85. Yoshitake S, Kimura A, Okada M, Yao T, Sasazuki T. HLA class II alleles in Japanese patients with inflammatory bowel disease. Tissue Antigens 1999;53(4 Pt 1):350-8.

86. Myung SJ, Yang SK, Jung HY, et al. HLA-DRB1*1502 confers susceptibility to ulcerative colitis, but is negatively associated with its intractability: A Korean study. Int J Colorectal Dis 2002;17:233-7.

87. Parkes M, Satsangi J, Lathrop GM, Bell JI, Jewell DP. Susceptibility loci in inflammatory bowel disease. Lancet 1996;348:1588. (Lett)

88. Bayless TM, Tokayer AZ, Polito JM II, Quaskey SA, Mellits ED, Harris ML. Crohn's disease: Concordance for site and clinical type in affected family members - Potential hereditary influences. Gastroenterology 1996;111:573-9.

89. Colombel JF, Grandbastien B, Gower-Rousseau C, et al Clinical characteristics of Crohn's disease in 72 families. Gastroenterology 1996;111:604-7.

90. Annese V, Andreoli A, Astegiano M, et al. Clinical features in familial cases of Crohn's disease and ulcerative colitis in Italy: A GISC study. Italian Study Group for the Disease of Colon and Rectum. Am J Gastroenterol 2001;96:2939-45.

91. Fernandez L, Mendoza JL, Martinez A, et al. IBD1 and IBD3 determine location of Crohn's disease in the Spanish population. Inflamm Bowel Dis 2004;10:715-22.

92. Yamamoto-Furusho JK, Uscanga LF, Vargas-Alarcon G, et al. Clinical and genetic heterogeneity in Mexican patients with ulcerative colitis. Hum Immunol 2003;64:119-23.

93. de la Concha EG, Fernandez-Arquero M, Martinez A, et al. Amino acid polymorphism at residue 71 in HLA-DR beta chain plays a critical role in susceptibility to ulcerative colitis. Dig Dis Sci 1999;44:2324-9.

94. Roussomoustakaki M, Satsangi J, Welsh K, et al. Genetic markers may predict disease behavior in patients with ulcerative colitis. Gastroenterology 1997;112:1845-53.

95. Bouma G, Crusius JB, Garcia-Gonzalez MA, et al. Genetic markers in clinically well defined patients with ulcerative colitis (UC). Clin Exp Immunol 1999;115:294-300.

96. Silverberg MS, Mirea L, Bull SB, et al. A population- and family-based study of Canadian families reveals association of HLA DRB1*0103 with colonic involvement in inflammatory bowel disease. Inflamm Bowel Dis 2003;9:1-9.

97. Orchard TR, Chua CN, Ahmad T, Cheng H, Welsh KI, Jewell DP. Uveitis and erythema nodosum in inflammatory bowel disease: Clinical features and the role of HLA genes. Gastroenterology 2002;123:714-8.

98. Orchard TR, Thiyagaraja S, Welsh KI, Wordsworth BP, Hill Gaston JS, Jewell DP. Clinical phenotype is related to HLA genotype in the peripheral arthropathies of inflammatory bowel disease. Gastroenterology 2000;118:274-8.

99. Schreiber S, Rosenstiel P, Albrecht M, Hampe J, Krawczak M. Genetics of Crohn disease, an archetypal inflammatory barrier disease. Nat Rev Genet 2005;6:376-88.

100. van Heel DA, Udalova IA, De Silva AP, et al. Inflammatory bowel disease is associated with a TNF polymorphism that affects an interaction between the OCTN1 and NF(-kappa)B transcription factors. Hum Mol Genet 2002;11:1281-9.

101. O'Callaghan NJ, Adams KE, van Heel DA, Cavanaugh JA. Association of TNF-alpha-857C with inflammatory bowel disease in the Australian population. Scand J Gastroenterol 2003;38:533-4

102. Negoro K, Kinouchi Y, Hiwatashi N, et al. Crohn's disease is associated with novel polymorphisms in the 5'-flanking region of the tumor necrosis factor gene. Gastroenterology 1999;117:1062-8. 
103. Mascheretti S, Hampe J, Kuhbacher T, et al. Pharmacogenetic investigation of the TNF/TNF-receptor system in patients with chronic active Crohn's disease treated with infliximab. Pharmacogenomics J 2002;2:127-36.

104. Louis E, Peeters M, Franchimont D, et al. Tumour necrosis factor (TNF) gene polymorphism in Crohn's disease (CD): Influence on disease behaviour? Clin Exp Immunol 2000;119:64-8.

105. Ferreira AC, Almeida S, Tavares M, et al. NOD2/CARD15 and TNFA, but not IL1B and IL1RN, are associated with Crohn's disease. Inflamm Bowel Dis 2005;11:331-9.

106. Levine A, Karban A, Eliakim R, et al. A polymorphism in the TNF-alpha promoter gene is associated with pediatric onset and colonic location of Crohn's disease. Am J Gastroenterol 2005; 100:407-13

107. Stoll M, Corneliussen B, Costello CM, et al. Genetic variation in DLG5 is associated with inflammatory bowel disease. Nat Genet 2004;36:476-80.

108. Yamazaki K, Takazoe M, Tanaka T, et al. Association analysis of SLC22A4, SLC22A5 and DLG5 in Japanese patients with Crohn disease. J Hum Genet 2004:49:664-8.

109. Daly MJ, Pearce AV, Farwell L, et al. Association of DLG5 R30Q variant with inflammatory bowel disease. Eur J Hum Genet 2005; 13:835-9.

110. Torok HP, Glas J, Tonenchi L, et al. Polymorphisms in the DLG5 and OCTN cation transporter genes in Crohn's disease. Gut 2005;54:1421-7.

111. Noble CL, Nimmo ER, Drummond H, Smith L, Arnott ID, Satsangi J. DLG5 variants do not influence susceptibility to inflammatory bowel disease in the Scottish population. Gut 2005;54:1416-1420.

112. Panwala CM, Jones JC, Viney JL. A novel model of inflammatory bowel disease: Mice deficient for the multiple drug resistance gene, mdrla, spontaneously develop colitis. J Immunol 1998;161:5733-44.

113. Langmann T, Moehle C, Mauerer R, et al. Loss of detoxification in inflammatory bowel disease: Dysregulation of pregnane $\mathrm{X}$ receptor target genes. Gastroenterology 2004;127:26-40.

114. Satsangi J, Parkes M, Louis E, et al. Two stage genome-wide search in inflammatory bowel disease provides evidence for susceptibility loci on chromosomes 3, 7 and 12. Nat Genet 1996;14:199-202.

115. Ho GT, Nimmo ER, Tenesa A, et al. Allelic variations of the multidrug resistance gene determine susceptibility and disease behavior in ulcerative colitis. Gastroenterology 2005;128:288-96.

116. Glas J, Torok HP, Schiemann U, Folwaczny C. MDR1 gene polymorphism in ulcerative colitis. Gastroenterology 2004;126:367. (Lett)

117. Schwab M, Schaeffeler E, Marx C, et al. Association between the C3435T MDR1 gene polymorphism and susceptibility for ulcerative colitis. Gastroenterology 2003;124:26-33.
118. Brant SR, Panhuysen CI, Nicolae D, et al. MDR1 Ala893 polymorphism is associated with inflammatory bowel disease. Am J Hum Genet 2003;73:1282-92. (Erratum in 2004;74:1080).

119. Croucher PJ, Mascheretti S, Foelsch UR, Hampe J, Schreiber S. Lack of association between the C3435T MDR1 gene polymorphism and inflammatory bowel disease in two independent Northern European populations. Gastroenterology 2003;125:1919-20. (Lett)

120. Gazouli M, Zacharatos P, Gorgoulis V, Mantzaris G, Papalambros E, Ikonomopoulos J. The C3435T MDR1 gene polymorphism is not associated with susceptibility for ulcerative colitis in Greek population. Gastroenterology 2004;126:367-9. (Lett)

121. Kugathasan S, Collins N, Maresso K, et al. CARD15 gene mutations and risk for early surgery in pediatric-onset Crohn's disease. Clin Gastroenterol Hepatol 2004;2:1003-9.

122. Ho GT, Lees C, Satsangi J. Pharmacogenetics and inflammatory bowel disease: Progress and prospects. Inflamm Bowel Dis 2004;10:148-58.

123. Vogel F. Moderne probleme der Humangenetik. Ergeb Inn Med Kinderheilkd 1959;12:52-125.

124. Kalow W, Tang BK, Endrenyi L. Hypothesis: Comparisons of inter- and intra-individual variations can substitute for twin studies in drug research. Pharmacogenetics 1998;8:283-9.

125. Colombel JF, Ferrari N, Debuysere H, et al. Genotypic analysis of thiopurine S-methyltransferase in patients with Crohn's disease and severe myelosuppression during azathioprine therapy. Gastroenterology 2000;118:1025-30.

126. Kader HA, Wenner WJ Jr, Telega GW, Maller ES, Baldassano RN. Normal thiopurine methyltransferase levels do not eliminate 6-mercaptopurine or azathioprine toxicity in children with inflammatory bowel disease. J Clin Gastroenterol 2000;30:409-13.

127. Black AJ, McLeod HL, Capell HA, et al. Thiopurine methyltransferase genotype predicts therapy-limiting severe toxicity from azathioprine. Ann Intern Med 1998;129:716-8.

128. Spire-Vayron de la Moureyre C, Debuysere H, Mastain B, et al. Genotypic and phenotypic analysis of the polymorphic thiopurine S-methyltransferase gene (TPMT) in a European population. Br J Pharmacol 1998;125:879-87.

129. Farrell RJ, Murphy A, Long A, et al. High multidrug resistance (P-glycoprotein 170) expression in inflammatory bowel disease patients who fail medical therapy. Gastroenterology 2000;118:279-88

130. Hoffmeyer S, Burk O, von Richter O, et al. Functional polymorphisms of the human multidrug-resistance gene: Multiple sequence variations and correlation of one allele with P-glycoprotein expression and activity in vivo. Proc Natl Acad Sci USA 2000;97:3473-8.

131. Sakaeda T, Nakamura T, Okumura K. Pharmacogenetics of MDR1 and its impact on the pharmacokinetics and pharmacodynamics of drugs. Pharmacogenomics 2003;4:397-410. 


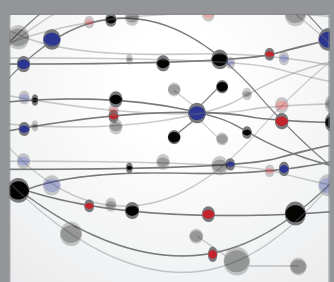

The Scientific World Journal
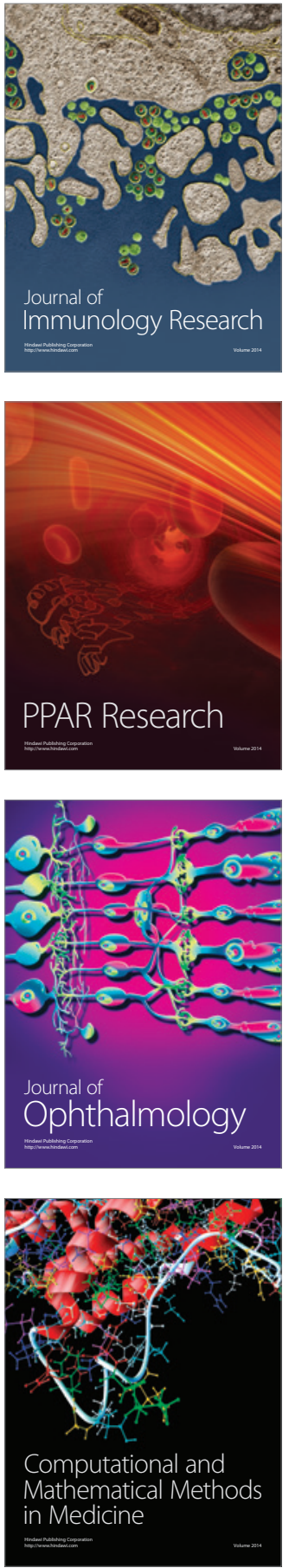

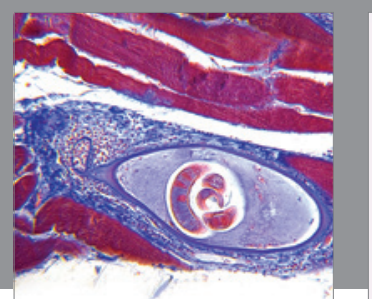

Gastroenterology Research and Practice

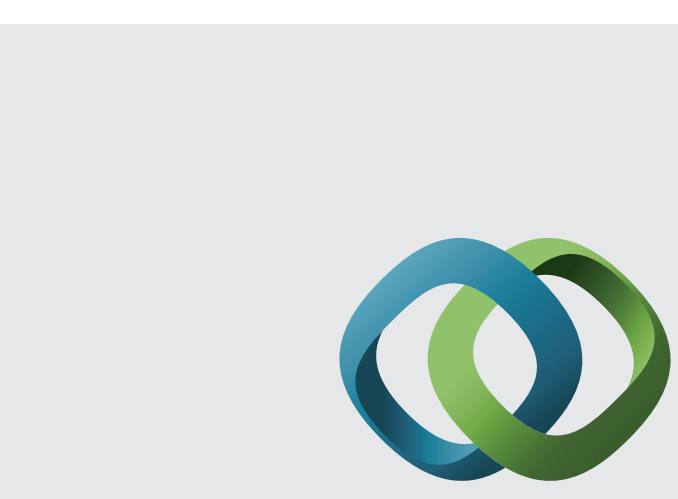

\section{Hindawi}

Submit your manuscripts at

http://www.hindawi.com
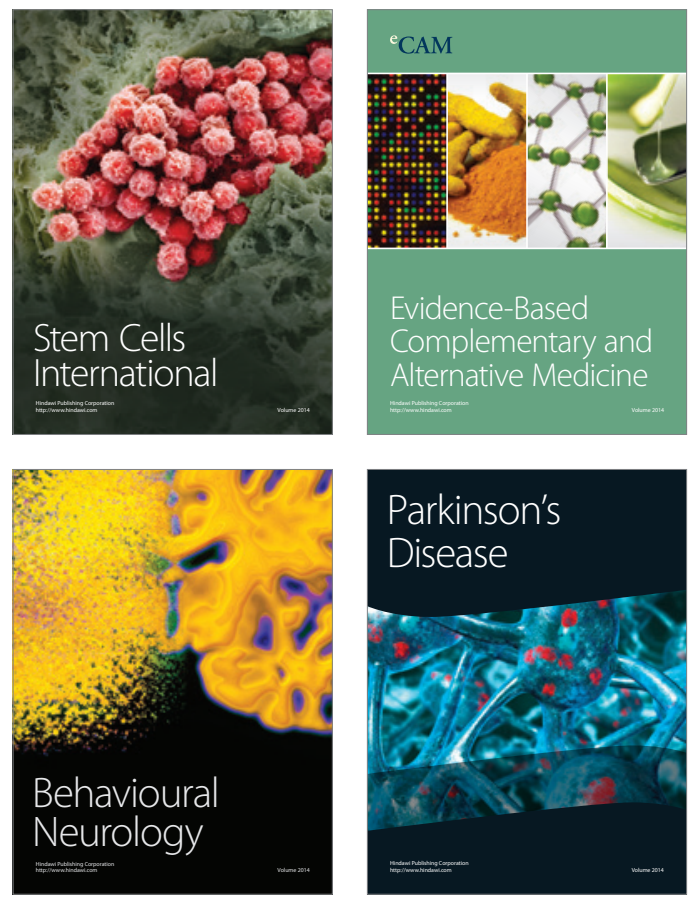
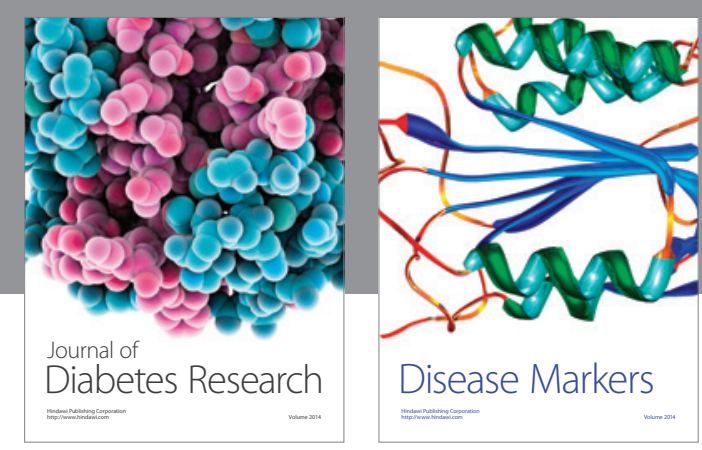

Disease Markers
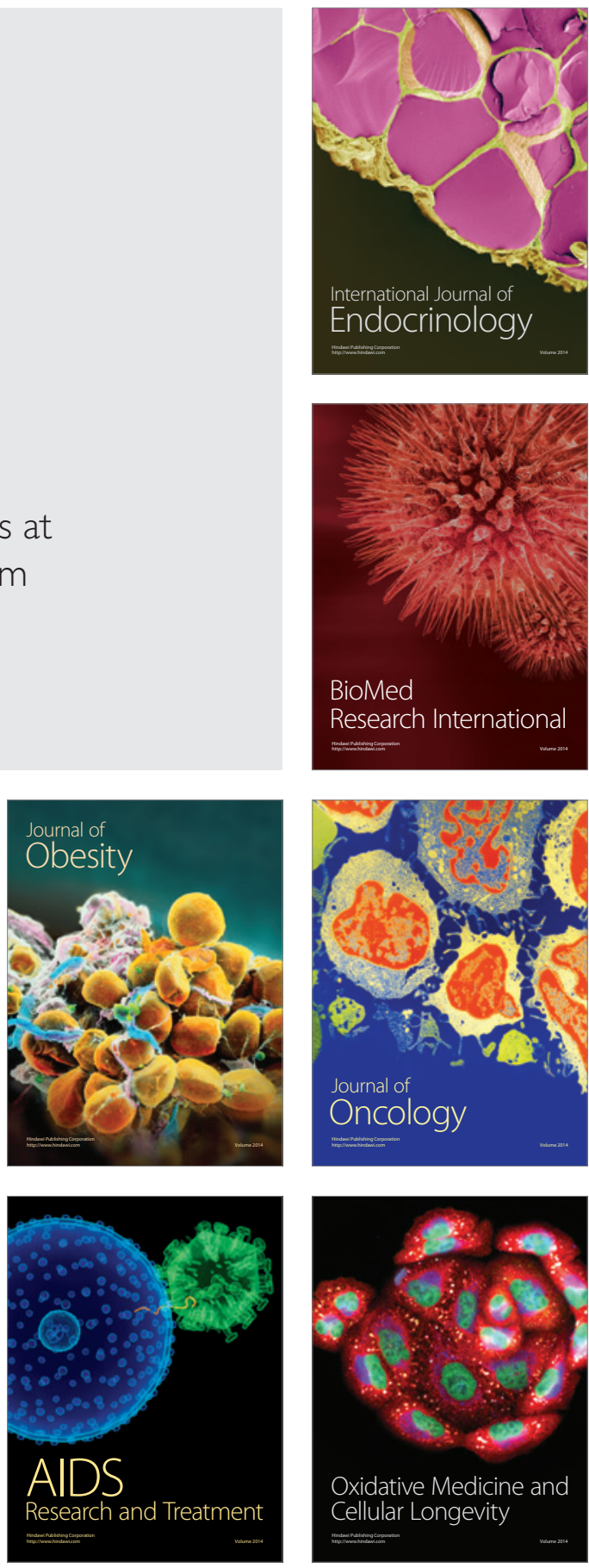